\title{
Symposium review: Future of housing for dairy cattle*
}

\author{
P. J. Galama, ${ }^{1} \dagger \odot$ W. Ouweltjes, ${ }^{1} \odot$ M. I. Endres, ${ }^{2} \oplus$ J. R. Sprecher ${ }^{3}$ L. Leso, ${ }^{4} \oplus$ A. Kuipers, ${ }^{1} \odot$ and M. Klopčič ${ }^{5}$ \\ ${ }^{1}$ Wageningen Livestock Research, PO Box 338, $6700 \mathrm{AH}$, Wageningen, the Netherlands \\ ${ }^{2}$ Department of Animal Science, University of Minnesota, 1364 Eckles Avenue, St. Paul 55108 \\ ${ }^{3}$ Sprecher Architects, Halamed Hey str. 10, Tel Aviv 6927710, Israel \\ ${ }^{4}$ Department of Agricultural, Food and Forestry Systems, University of Florence, Via San Bonaventura, 13, IT-50145 Firenze, Italy \\ ${ }^{5}$ Department of Animal Science, Biotechnical Faculty, University of Ljubljana, Groblje 3, Domžale, Slovenia
}

\section{ABSTRACT}

The objective of this review was to describe recent changes and expected developments in housing systems for dairy cows. These new developments should create an appropriate production environment for modern high-producing dairy cows and stimulate dairy farmingrelated developments in management, agro-technology, and equipment. Increased labor efficiency has been an important driver of the change from tie-stall barns to cubicle barns (also known as freestall barns). In future housing systems, the natural behavior of cows, climate control, emissions of ammonia and greenhouse gases, reuse of waste, manure quality, the aesthetics of buildings in the landscape, and capital efficiency are becoming increasingly important elements. To address future requirements, new concepts beyond cubicle barns must be developed. Freewalk housing systems; that is, loose housing systems without cubicles, would meet some of these future demands. These systems operate with composting bedding material or artificial permeable floors as lying and walking areas. However, these barns are still in development. Combinations of cubicle and freewalk housing systems, together with other techniques being developed, might become a major future housing system. Other techniques and systems that are being explored according to sustainability criteria include the multi-climate shed, the CowToilet (Hanskamp AgroTech, Doetinchem, the Netherlands) to separate feces and urine, and multifunctional buildings. These buildings and techniques can be part of land-based or, less commonly, city-based farming systems, such as floating farms.

Received July 5, 2019.

Accepted February 12, 2020.

*Presented as part of the Production, Management, and the Environment Symposium: Future of Housing for Dairy Cattle at the ADSA Annual Meeting, Cincinnati, Ohio, June 2019.

†Corresponding author: paul.galama@wur.nl
Key words: housing, welfare, environment, innovation, dairy cattle

\section{INTRODUCTION}

The development of different housing systems in previous decades has been driven primarily by technical innovations required by changes in cow requirements, farmer demands, and societal and environmental impact (national and local). These requirements and demands differ among countries, resulting in a wide variety of dairy housing systems. In many countries, tie-stalls (TS) remain in operation, but cubicle housing systems (CB, cubicle barns), often called freestall barns, have been widespread since the 1970s (Bewley et al., 2017). Technical innovations in feeding and milking made the transition to $\mathrm{CB}$ possible. However, studies by Somers et al. (2003) and Leso et al. (2020) have shown that the prevalence of lameness and hock lesions can be high in CB on concrete flooring, including both slatted and solid floors. Therefore, farmers are searching for solutions to prevent lameness and further improve animal welfare. Bewley et al. (2017) noted that freewalk housing systems (FW), especially beddedpack barns, have become of interest globally. Because of the growing international focus on animal welfare, providing space for cows to express natural behaviors is becoming more important (Beaver et al., 2019). Freewalk systems are spreading in several areas, such as Western Europe, Brazil (Fávero et al., 2015), and in the United States (Kentucky and Minnesota; Barberg et al., 2007; Black et al., 2013). In Israel, the FW system is already widely adopted (Klaas et al., 2010). New developments in housing systems may create conflicts with other sustainability goals such as protecting the environment. Holistic solutions should be found that can be adapted to local conditions, such as climate and regulations. This article describes developments in housing systems with respect to the evolution of sustainability goals and technical innovations, with a focus on new developments and the future outlook. 


\section{DEVELOPMENTS IN HOUSING SYSTEMS}

Appendix Figure A1 shows the development of dairy housing from the past (before the 1970s) into the future (2020-2030). Although the focus is from a Western European perspective, the evolution toward more sustainable farming systems is occurring worldwide. The barn is an important element of farm operation because it affects sustainability aspects - the environment, cattle welfare, and economics. Before the 1970s, TS were common. The TS system fits bucket milking systems and hay feeding, and makes it relatively easy to keep the animals clean; however, it is not ideal for animal welfare because of the lack of freedom of movement, limited space $\left(\mathrm{m}^{2}\right)$ per cow, and the potential for teat and leg injuries. Moreover, TS are not optimal for labor efficiency. Several factors explain the gradual change from TS to CB since the 1970s, although improvements have still been achieved in TS, such as the use of milk pipelines, stall size adjustments, the removal of trainers, and the use of more suitable feeding practices (Bewley et al., 2017). The transition to CB was stimulated by the development of parlor milking systems, cooling milk in a tank, grass silages, and other innovations, thereby increasing labor efficiency. Bewley et al. (2017) have also described easy separation of lactating cow groups and feeding of TMR in CB. The higher labor efficiency in CB has allowed for farms to be scaled up. However, in $\mathrm{CB}$, cows walk on a concrete floor, which can cause hoof problems (Kester et al., 2014), and the manure product changes from feces mixed with straw and urine in TS to slurry in CB.

Since the mid-1980s, after approximately 15 yr of experience with $\mathrm{CB}$, milk production increased through improvements in genetics, technology, and milking and feeding management (Khanal et al., 2010), whereas animal welfare issues and minimizing ammonia emissions during field manure application increased in importance. The need for cow comfort was addressed by innovations such as mattresses in stalls; the use of deep sand, straw, and manure solids as bedding; innovative cubicle partitions (rigid vs. flexible) that decrease cow injuries; open sides of barns; curtains to regulate ventilation; higher and insulated roofs; and wider walking areas. Sand is considered the gold standard for deepbedded cubicles, but handling of sand-loaded manure may pose some challenges (Palmer and Holmes, 2005). Until 1985, manure was spread above the ground, thus leading to high ammonia emissions and strong odors. Therefore, new manure application techniques were developed, such as disk injection.

Currently, environmental and cattle welfare requirements are becoming even more stringent. In addition to ammonia emissions (related to acidification), decreasing the emission of greenhouse gases (GHG; related to climate change) has gained importance (Steinfeld et al., 2006). New techniques, such as capturing emissions in the barn and separating feces and urine, are being tried out in practice. Also, housing conditions and grazing affect animal welfare and emissions. Grazing of cows is promoted in some global regions. However, grazing can be difficult for farmers with large herds, milking robots, and insufficient land around the farm (Schils et al., 2018). Grazing is stimulated in some countries because the public likes to see cows in the landscape and because grazing is believed to be beneficial for cow health and welfare (Beaver et al., 2019). In the Netherlands, milk cooperative processors pay a higher price for milk from grazed cows (an additional €0.015/ $\mathrm{kg}$ when cows graze for more than $6 \mathrm{~h} / \mathrm{d}$ for more than $120 \mathrm{~d}$ ). In addition, the aesthetics of buildings in the landscape is becoming an issue because of the construction of larger barns as a result of the need for more space per cow and increasing herd sizes.

To address these issues, a network of Dutch dairy farmers began searching for alternatives to $\mathrm{CB}$ from 2007, aiming to substantially improve animal welfare, reduce environmental impacts, increase manure quality, and be cost-effective. Additional arguments for alternatives included that more dairy cattle are kept in zerograzing systems (CBS, 2017), emphasizing the need for optimal welfare of cows kept indoors year-round. These indoor systems are also dominant in the United States (USDA, 2016). Moreover, an increasing number of dairy farmers in intensive dairy regions in Western Europe and some regions in the United States lack enough land to apply all manure produced and consequently export manure from their farms (Clay et al., 2020). Cattle slurry from CB contains a high percentage of water and low OM content and, in some regions, farmers must pay to export this manure. To obtain a less voluminous product and increase soil fertility, farmers in this "Dutch dairy learning network" chose manure with more OM, such as composted bedding material. This network learning process in combination with applied research on experimental facilities and 10 commercial farms was described by Galama et al. (2012). Researchers and dairy farmers exchanged ideas and visited the United States and Israel to view concepts of housing systems without cubicles. Consequently, the option of freewalk barns, such as bedded-pack barns, became a research focus. Moreover, experiments and discussions among experts indicated benefits of animal welfare and manure quality as well as trade-offs (Galama et al., 2012), such as (1) more space per cow versus more ammonia and nitrous oxide emission, (2) using waste ma- 
terials as bedding versus increased food safety risk, (3) limited availability of bedding material (mostly wood chips or sawdust) at an affordable price, and (4) larger buildings versus landscape quality. Subsequently, ideas were proposed for better management of the bedding and farm designs with different roofs and floor types. However, the implementation of FW systems is still in development. This ongoing learning cycle is described by the DEED model (Describe, Explain, Explore, and Design; Giller et al., 2008).

As of 2019, approximately 55 Dutch farms have built an FW bedded-pack barn system, mostly with wood chips as bedding material. Approximately half of these farms have adopted a greenhouse-type building, thus resulting in low investment for roof construction to compensate for the investment in greater area $\left(\mathrm{m}^{2}\right)$ per cow. Moreover, other alternatives to concrete floors, such as artificial floors, have been investigated. Knowledge exchange between countries intensified, thus resulting in the EU project FreeWalk (www.freewalk.eu), involving 8 European countries. The aim of the project is to further develop FW cattle farming systems, which are expected to improve animal welfare and soil structure, utilize waste products, and have greater public support than CB systems.

\section{FUTURE PERSPECTIVES}

\section{Goals and Conditions}

Recent societal demands have prompted animal husbandry farmers to provide a license to produce. For example, in the Netherlands, milk processors have developed the "Sustainable Dairy Chain" program (Duurzame Zuivelketen, 2017). The overall aim of this program is for people to work safely and with pleasure in the dairy sector, with fair income and high-quality food; for farmers to handle their animals and the environment respectfully; and for the sector to be appreciated by society. The smart objectives of this program in 2020 are climate-neutral development (20\% reduction in GHG compared with 1990 data; 16\% sustainable energy; energy-efficiency $+2 \%$ /year); maintained grazing (81.2\% of farms should use grazing); continuous improvement of animal welfare and health $(70 \%$ reduction in antibiotic use; longevity +6 mo compared with 2011); improved welfare scores (in operation by 2017); maintenance of the environment (100\% use of responsible soy; national phosphate usage at 2002 level; and a 5-kt reduction in ammonia emissions compared with 2011); and improved biodiversity (biodiversity tool available in 2017). The milk processors stimulate these goals by paying a higher price for milk with a low carbon footprint. Goals are annually monitored by Wageningen Economic Research (Wageningen, the Netherlands). A sector team actively helps to achieve each goal, all of which are intended to be in line with the ever-increasing influence of society, which in the short term may be more dominant in Europe than in the United States and Asia. In 2020, new goals will be set for the dairy sector in line with societal goals.

Since 2019, the European Union has placed more emphasis on a circular economy in agriculture, focusing on upgrading waste, energy production, reducing GHG, and improving soil quality in relation to crop production, biodiversity and natural land (Horizon Europe, 2019). Because of climate change, heat stress in cattle becomes more relevant. In cattle welfare, a likely focus will be on the natural behavior of cows with access to outdoor exercise or grazing and calf-friendly rearing systems (Ventura et al., 2016). Our expectation is that, worldwide, animal welfare, acidification (ammonia emissions), climate change (GHG), and biodiversity will receive increasing attention.

Dairy housing systems can affect all these aspects through 4 different routes: (1) improved production efficiency and healthier cows, resulting in more milk per cow with a lower carbon footprint; that is, less emissions; (2) innovative floor types and storage of manure solids (feces) and liquids (urine), such as floors separating feces and urine or floors with bedding material in FW systems working as a biofilter; (3) delivery of a manure product that works as a soil improver (carbon sequestration); and (4) fewer young stock, as better animal health reduces the frequency of stock replacement.

A challenge in future housing is creating designs that resolve conflicts in existing $\mathrm{CB}$ or FW housing systems. An important factor is the amount of space $\left(\mathrm{m}^{2}\right)$ per cow (Figure 1). More space offers the possibility of more natural behavior but tends to have a drawback of more ammonia emissions per cow because of the greater emitting surface per cow. In contrast, FW with composted bedding material may have the capacity to absorb nitrogen (Hammond, 2015). In addition, more space per cow directly affects building size. In this context, farmers and architects are searching for solutions, especially regarding roof type in relation to costs, light, ventilation, and landscape. The roof types differ among countries, depending on rainfall, wind speed, snow load, and aesthetic acceptance in relation to the landscape.

\section{Freewalk Housing-Bedded-Pack Barn}

Several articles have described the advantages and disadvantages of FW bedded-pack barns (Endres and 
Barberg, 2007; Bewley et al., 2017). Endres and Barberg (2007) indicated that compost dairy barns (a type of FW system) can be an adequate housing system for dairy cows, based on observations of lying behavior, social interactions, and natural lying positions in 12 farms in Minnesota. The results of the European FreeWalk project by Blanco-Penedo et al. (2020) indicate that cows take less time to lie down and stand up and have fewer injuries in FW than in CB. Bewley et al. (2017) and Leso et al. (2020) have indicated advantages such as less lameness and fewer hock lesions and more natural behaviors in FW bedded-pack barns than $\mathrm{CB}$, but also described the disadvantages - the amount of bedding material needed and the difficulty in managing the bedding properly.

Since 2009, approximately $55 \mathrm{FW}$ bedded-pack barns have been built in the Netherlands, 24 of which are involved in the FW project. The farms differ in farm design and bedding type and management. Most farms use wood chips as bedding material and compost this material, mixed with the feces and urine of the cows, in the barn. The heat of the composting process stimulates the evaporation of moisture. Most farmers control the composting process with an aerating system by blowing or sucking air through the bedding. In the past, some farmers have used green waste from compost factories as bedding. Since January 2015, this type of compost has been prohibited by Dutch milk processors in both $\mathrm{FW}$ and $\mathrm{CB}$, because of an increased concentration of thermophilic aerobic spore-forming bacteria in milk from cows kept on such bedding, which may lead to quality defects in sterilized dairy products (Driehuis et al., 2012).

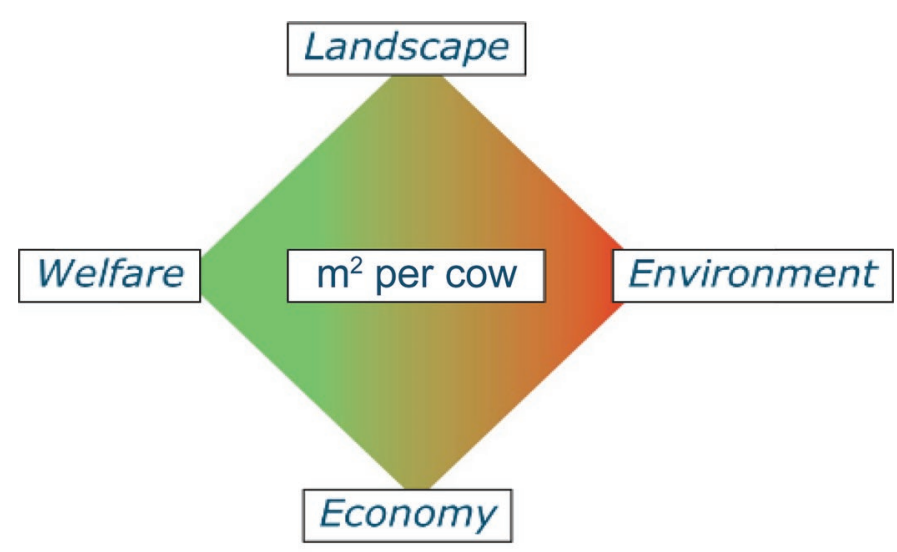

Figure 1. Drivers and potential conflicting factors (green and red, respectively) in housing design in relation to more available space per cow.
In Israel, the FW housing system with dried manure as bedding is predominant. The ammonia emission from this bedding system is expected to be high because of the increased space per cow. However, a study by van Dooren et al. (2019) showed lower overall ammonia emissions compared with CB housing.

Another point for further development is disposing of wastewater in the bedding. In a dry climate, milking parlor wastewater can be spread into the bedding. The aeration and composting process helps evaporate the water while the compost bedding retains the minerals contained in the wastewater. Consequently, the farm no longer discharges large amounts of wastewater into the sewer system, resulting in operational cost savings and decreasing the load on public sewage systems.

In a dry climate, an entire building area could be dedicated to walking and lying areas for cows and young stock. Such barns have no feed alley for tractors and no slatted or solid floor (cow lane) along the feeding fence. Feeding is done with simple mobile feed troughs spread around the bedding area, which are moved daily to prevent the bedding areas around the feeders from becoming excessively dirty. All feces and urine go into the bedding; therefore, no slurry must be removed from solid walking floors. The capital expenditure for this type of barn is approximately $40 \%$ less than that of traditional FW barns, according to J. R. Sprecher (Sprecher Architects, Tel Aviv, Israel; personal communication). A similar solution has been implemented in Italy, where farmers have chosen to build an FW housing system with no feed alley or cow lane along the feeding fence to reduce the volume of slurry effluent (Leso et al., 2018).

A dry climate facilitates spreading waste water on the bedding and using the whole building as a lying and walking area. To keep the bedding dry in areas with high humidity, it is important to have sufficient area per cow, sufficient bedding height, and dry bedding material, whereas an active aerating system can stimulate the composting process to evaporate the moisture out of the bedding (Galama et al., 2015).

The type of bedding material used in FW housing systems differs among countries, depending on local price and availability. Materials used include sawdust, wood chips, wood shavings, miscanthus grass, rice hulls, soybean stubble, straw, peanut shells, and coffee husks (Leso et al., 2020).

Recently, producers in Europe have attempted to use sand as a bedding material in FW and found encouraging results (L. Leso, unpublished data). Sand is inorganic and can drain urine through the bedding, and it is known to have positive effects on cow health and comfort (Lombard et al., 2010; Adams et al., 2017). 
However, handling sand-loaded manure poses several challenges. In the context of FW housing, a sloped floor beneath the bedded area could be used to push the sand-loaded manure to the cow lane along the feeding fence, where it could be removed with a scraper or a flush system. With a sand separator, the sand can be recovered and reused, potentially reducing the costs for bedding materials in FW. The use of recycled sand, however, may increase the OM content and bacterial count in the bedding, thus potentially increasing the risk of mastitis (Rowbotham and Ruegg, 2016: Kull et al., 2017). Because experience in using sand in FW remains limited, further research is warranted to explore the potential benefits of this material.

\section{Freewalk Housing-Artificial Floor}

A new development in FW housing is barns with permeable artificial floors composed of different layers. On top is a special drainage fabric that lets urine pass through and keeps feces above the floor. A mattress under the top layer is soft enough for the cows to walk on but hard enough for a manure robot to scrape the feces. Boxes on the bottom of the floor construction collect the urine, and pipes underneath transport it to a storage system. The first artificial floor farm combines an artificial floor with trees in the barn. Trees make the building more visually appealing and create shade for the cows, because substantial light comes through the transparent roof (Figure 2). This particular housing system is called a cow garden.

In a recent experiment, Leso et al. (2017) evaluated the thermal performance of a greenhouse-type building with a living plant canopy as an alternative to conventional barns. The results showed that the use of greenery systems such as a plant canopy can effectively reduce the internal temperature of the building. During severely hot weather, a greenhouse-type barn with transparent cladding and a living plant canopy has been found to have the same internal temperature as a conventional building with insulating panel roofing.

A manure robot completes the artificial floor FW system. The robot collects manure from the upper layer of the artificial floor and deposits it in a central gutter. This collection technique differs from other techniques of sucking or pushing the manure. The manure robot was developed to clean the floor 3 to 6 times per day, depending on the area per cow (10 to $16 \mathrm{~m}^{2}$ per cow). A limited number of artificial floor $\mathrm{FW}$ barns are in operation or in the process of being built in the Netherlands, Slovenia, and Germany (approximately 10 farms, including experimental farms). Observations with this floor system have revealed several factors critical to

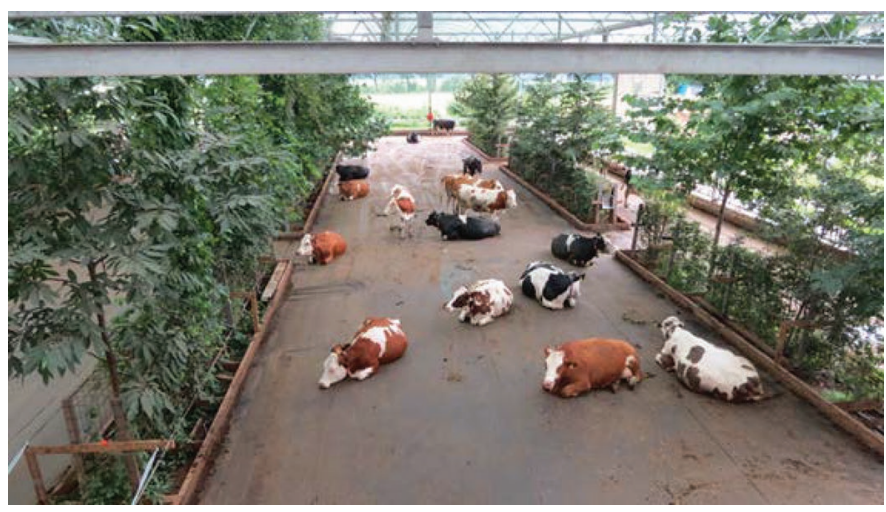

Figure 2. Cow garden with artificial floor separating urine and manure, and small trees for shade and a natural look (Kraanswijk farm, Groenlo, the Netherlands).

keeping the floor and the cows clean: the settings of the manure robot, the battery capacity, the construction of the floor, and sufficient natural ventilation at floor level. Farmers have expressed interest in investing in artificial floors because of animal welfare concerns and the ability to separate feces and urine, thus optimizing the use of $\mathrm{N}, \mathrm{P}, \mathrm{K}$, and $\mathrm{OM}$.

In a case study in the FreeWalk project, cow behavior on an artificial floor has, for the first time, been compared with that of cows kept on a composted wood chip bedding and cows housed in a traditional CB. This study was performed on 3 commercial farms with 90 to 100 cows, all with milking robots and access to pasture during the grazing period. Differences in behavior are strongly affected by lying space and the management of the housing system; for instance, the influence of the manure robot on the artificial floor, the cultivation of the wood chip bedding, and the cubicles as an obstacle to free movement. The $\mathrm{CB}$ had $3.4 \mathrm{~m}^{2}$ lying space per cow, the FW bedded-pack barn had $13.3 \mathrm{~m}^{2}$, and the FW artificial floor barn had $15.5 \mathrm{~m}^{2}$. Measurements were performed with IceQube sensors (IceRobotics, South Queensferry, UK) attached to 20 lactating cows in each herd. Every 2 mo over the course of $1 \mathrm{yr}$, approximately half of the sensors were transferred to other cows. Preliminary results from the indoor period indicated higher activity for cows in the $2 \mathrm{FW}$ housing systems (number of steps: $85 / \mathrm{h}$ for artificial floor, $50 / \mathrm{h}$ for bedded-pack, and $44 / \mathrm{h}$ for CB) and slightly shorter lying time (41\% of time for artificial floor, $42 \%$ for bedded-pack, and $48 \%$ for CB) and fewer lying bouts than those in the CB system (8.3 lying bouts for artificial floor, 7.9 for bedded-pack, and 9.0 for $\mathrm{CB}$ ), and all traits differed significantly between farm types (at $P<$ 0.001). However, the results in these distinctly different barn types might have been confounded by the farmers. 
Table 1. Comparison of freewalk bedded-pack and freewalk artificial floor to cubicle housing

\begin{tabular}{llcc}
\hline & & \multicolumn{2}{c}{ Freewalk $^{1}$} \\
\cline { 3 - 4 } Aspect & Criterion & Bedded-pack & Artificial floor \\
\hline Economics & Investment & - & - \\
& Yearly cost & + & $?$ \\
Cow & Longevity & + & $?$ \\
Environment & Production, health & + & + \\
& Welfare & + & $?$ \\
Manure quality & Ammonia emissions in barn & + & $?$ \\
& Ammonia emissions on land & - & + \\
& Greenhouse gases & - & + \\
\hline
\end{tabular}

${ }^{1}$ Where $+=$ positive $;-=$ negative; $?=$ under investigation.

Therefore, a more controlled study comparing the same housing systems indoors is currently being conducted at the research facility Dairy Campus (Leeuwarden, the Netherlands). Floor cleanliness is another major factor to consider, which largely depends on the manure robot functionality and the quality of the floor's top layer.

\section{Comparison of FW and $C B$}

Ten commercial farms in the Netherlands were monitored for welfare, environmental aspects, and manure quality. The economics was evaluated through observations and model calculations (Galama et al., 2015). In addition, ammonia emissions in different housing systems were measured in 3 commercial farms and at the research facility Dairy Campus (Leeuwarden, the Netherlands). Strengths and weaknesses of the FW bedded-pack barn and the FW artificial floor compared with $\mathrm{CB}$ are shown in Table 1 . Several aspects of the artificial floor, however, cannot yet be fully evaluated.

To compare the annual costs of FW with $\mathrm{CB}$, many assumptions must be made regarding costs and regulations on building structure, which differ among countries. The investment cost for FW bedded-pack barns can be lower than those for CB because of reduced concrete requirements and barn features (Barberg et al., 2007). However, for countries such as the Netherlands, a concrete floor is needed below the bedding area. Galama et al. (2015) calculated an investment of $€ 642 /$ cow for FW with wood chips as bedding. The roof is twice as expensive because of the greater area per cow. In contrast, the costs for manure storage are half as much, because the bedding area is also used for manure storage. Total annual costs were $€ 125 /$ cow higher because of $€ 62$ greater investment for the building, €153 more for bedding supply, €32 more for energy costs, and €21 more for mechanization and facilities (aerating system). Other costs for manure application and manure export were $€ 117$ lower and labor costs were $€ 26$ lower per cow per year. The profitability of FW depends primarily on the space per cow needed, price of bedding material, and the effect of better animal welfare on cow production and longevity. Preliminary results of the European FreeWalk projects have indicated large differences in the prices of bedding materials (from $€ 100$ to more than $€ 300$ per tonne) and inconsistent availability. The ammonia emissions of the FW housing with wood chip bedding material are $31 \%$ lower per cow than those of the CB system, whereas methane emissions are $34 \%$ higher per cow (van Dooren et al., 2019). The composted bedding material of $\mathrm{FW}$ with wood chips is a good soil improver, but the mineralization of $\mathrm{N}$ is slower than that with slurry (Galama et al., 2015). The permeable artificial floor provides an opportunity to separate the feces from the urine; feces is a good soil improver and urine is an effective fertilizer (van Dijk and Galama, 2019).

The expected effects, as listed in Table 1, may differ among regions, especially between northern and southern countries, because of climate. New approaches to limit emissions have entered the dairy housing scene, utilizing the characteristics of both $\mathrm{CB}$ and FW. Examples are the capturing of GHG and ammonia emissions in the barn and the use of the CowToilet (Hanskamp). These techniques will be further explored in the next sections.

\section{Separation of Feces and Urine in $C B$}

The expectations for future floor types in $\mathrm{CB}$ in environmentally progressive countries are floors able to separate feces and urine and maintain walkability, because of the decreased ammonia emissions due to separation, the decreased methane emission due to rapid removal from the barn, and the possible creation of different manure products for efficient use of $\mathrm{N}, \mathrm{P}$, 
$\mathrm{K}$, and $\mathrm{OM}$ carbon. The separation of urine and feces can be performed with a grooved floor that separates in a horizontal direction; by using plates that separate in a vertical manner, such as an artificial floor; or by using a belt underneath a slatted floor. A current innovation is the CowToilet (Hanskamp; Figure 3), invented based on research on defecating and urinating behaviors (Verdoes and Bokma, 2017). When a cow is at a concentrate feeder, she is stimulated to urinate by the moveable toilet gently touching the nerve at the back of her udder for a maximum of 2 min; then, when the urination response occurs, the toilet collects the urine. This technique results in better separation of feces and urine than separation on the floor, but not all urine will be collected by the CowToilet. A CowToilet in combination with FW systems might also help to decrease bedding moisture content. We suggest that the CowToilet may be most appropriate when combined with other high-tech applications, such as concentrate feeder boxes and, less favorable, robot milking boxes.

All of these options of floor types and separation techniques are currently in development and are expected to affect future housing layout and management.

\section{Comparison of Manure Products}

In recent years, animal welfare, reduction of GHG emissions, and manure quality in relation to soil structure and soil life have become more dominant concerns. The future of FW and $\mathrm{CB}$ depends on combining this aspect of manure quality with the other sustainability criteria. The design of a cow barn affects manure quality, which is important for use as fertilizer or soil improver on grassland and arable land, and for decreasing ammonia emissions. In this context, the economic value of 10 manure products has been evaluated (van Dijk and Galama, 2019) from the perspective of the dairy farmer who delivers it and the arable farmer who receives it. The revenues relate to fertilizer savings $(\mathrm{N}, \mathrm{P}$, and $\mathrm{K}$ ) and OM supply for improving soil fertility and quality and crop production. The total costs include the cost of an adapted housing system, (mechanical) separation, sampling and analysis, and transport and application onto the field. Organic manures from straw bedding are of interest as fertilizers and soil improvers, but the benefits must be weighed against the relatively high cost of straw. Therefore, farmers are searching for inexpensive bedding materials with high $\mathrm{OM}$ content that can be used in $\mathrm{CB}$ or FW barns. Mechanical separation of solids and liquids is expensive and might increase emissions. Consequently, primary separation of feces and urine with a different floor type in CB systems, use of a CowToilet, or separation by using an artificial

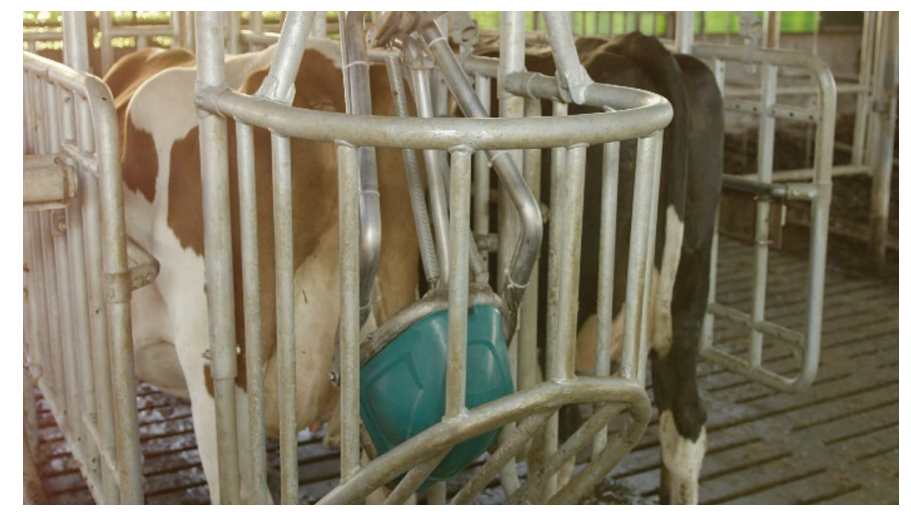

Figure 3. CowToilet for collecting urine from the cow (Hanskamp, Doetinchem, the Netherlands).

floor in FW housing systems is expected to result in a more sustainable dairy farm and may offer crop farmers more opportunities to select the right fertilizer or soil improver.

\section{Combining Innovations}

The techniques in $\mathrm{CB}$ and $\mathrm{FW}$ housing systems presented here remain in development. Combination and integration of these techniques and practices such as separation of feces and urine, cultivating bedding materials, and capturing urine and gases, together with implementation of technologies such as robotic milking and automatic feeding, might be components of future housing systems.

Following discussions about farming in areas with high stocking rates and high pressure to reduce emissions, Sprecher (2019) has described a new housing system, the multi-climate shed. Different innovations are combined in this building, which is expected to reduce ammonia and methane emissions. The multiclimate aspect is achieved with a "tent" type additional roofing above the feeding area (see Appendix Figure A2 for cross-section of building). This tent creates a microclimate within the entire building with respect to temperature, humidity, and fresh air, and it provides the possibility of removing gases (ammonia and methane) and odors. The V shape of the tent structure enables the collection and removal of air. The "in-house biofilter" (bedding with wood chips) filters the emission of ammonia and odor by transporting the air on top of the building through pipes toward the floor beneath the bedding into the bedding material. The multi-climate shed as a whole system has not been built yet, but its elements have already been implemented or are in development in practice. Biofilters with woodchips outside the building are used in pig farms (e.g., Hartmann 
Biofilters, Lichtenau, Germany). The multi-climate shed will use a biofilter with cattle kept on top of it. Methane gas will be burned when the air is released from the barn by passing through a burner or flame outlet. This technique is presently being tested at a dairy farm by burning the methane from manure storage (R. W. Melse, Wageningen University \& Research, Wageningen, the Netherlands, personal communication). One question is whether the concentration of methane in the air in cattle housing might be at a sufficient level to make its capture efficient. The combination of all these techniques in cattle housing is in the planning stage and is expected to be implemented in the recently started EU project ClimateCareCattle farming (https:/ /webhub.lsmuni.lt/ webccc/cccfarming/en).

To make housing systems more acceptable to society, the long-term effect on the landscape should be limited and the environmental footprint of the building lowered by making the building "deconstructable" and by using reusable and recyclable materials. The concept of "design for deconstruction" has emerged in building science during the past decade. Essentially, the concept includes provisions for the reuse of building materials at the end of the structure's life (Rios et al., 2015). To date, this concept has been poorly applied in agriculture, although it has the potential to reduce

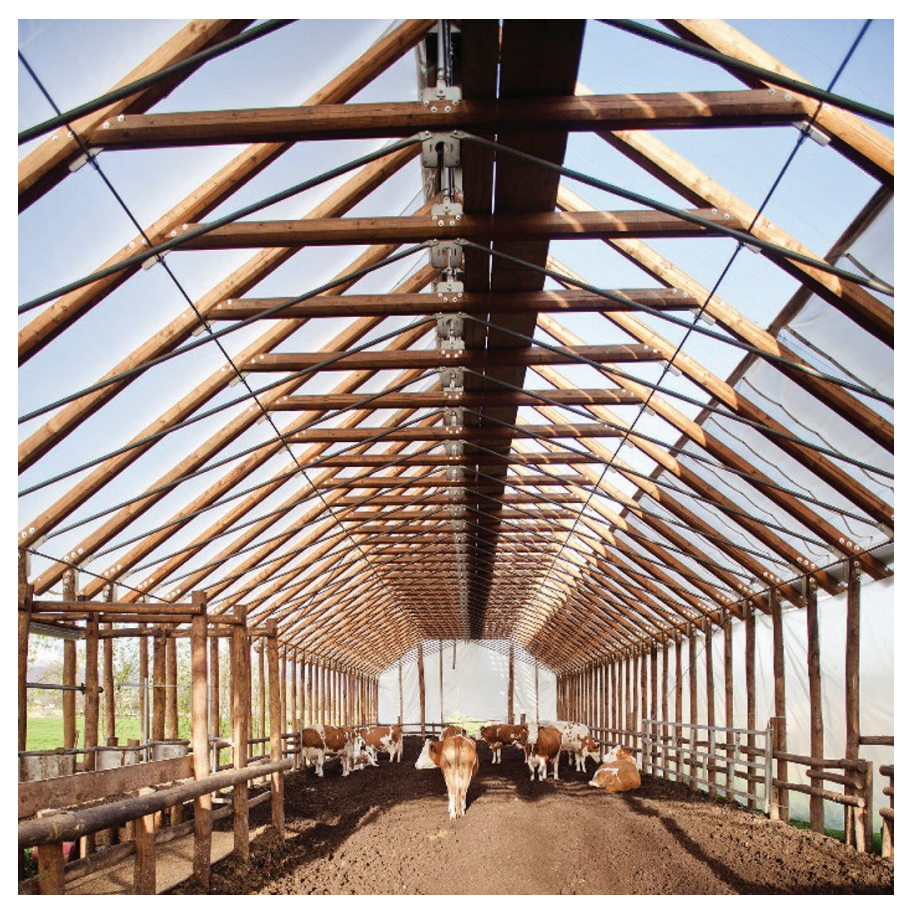

Figure 4. Barn for end-of-use disassembly and reuse of materials (Coop Tesori Bio farm, Cuneo, Piedmont, Italy). the whole-life environmental impact of farm facilities, including livestock housing.

An experimental FW barn designed for complete end-of-life disassembly and reuse of building materials has recently been built in Italy (Figure 4; Leso et al., 2018). The structural system consists of locally sourced timber connected by steel joints. Chestnut wood piles driven into the ground were used as foundation. A waterproof plastic film was placed underneath the 1-mdeep bedded-pack to avoid nutrient leakage and further limit the use of cast-in-place concrete, which is largely used in conventional housing systems.

To further accommodate societal preferences, the layout of the future barn should also consider access to grazing and potentially keeping calves with their dams (Ventura et al., 2016). Because grazing is common practice in many regions, a vast range of solutions have been developed to allow cows to access and use the pasture efficiently. In recent years, some key innovations have been developed to allow the use of automatic milking systems in pasture-based dairy farms (Jacobs and Siegford, 2012). Rearing calves with the dam, however, is a relatively novel issue in the dairy sector, which poses some challenges. Early cow-calf separation is standard practice in dairy operations, because it is believed to favor milk production and reduce the risk of transfer of pathogens from the dam to neonatal calves. In contrast, Meagher et al. (2019) have shown more normal behavior associated with extended cow-calf contact, and Johnsen et al. (2016) showed that prolonged cowcalf contact may provide longer-term benefits for calf growth and behavioral development, with no consistent evidence for a reduction in milk yield for the cow. They also mention that udder health of the cow can be positively affected by nursing. In this respect, the greater space provided to animals in FW housing may allow the calves to be kept with the cows for longer periods.

\section{Multifunctional Buildings}

Future housing designs are expected to combine features of FW and CB. For example, FW could be used for young stock, dry cows, special needs cows, and fresh cows that benefit the most from the soft surface and large space allowance. The management of bedding in FW is easier for young stock and dry cows, because the amount of moisture from these animals is much lower per animal than from high-producing cows. In such a system, high-yielding dairy cows could be kept in welldesigned cubicles with animal-friendly bedding, such as deep sand, and with low-emission walkable floors. Alternatively, the FW area could also be implemented as an environmental and welfare-friendly exercise area 

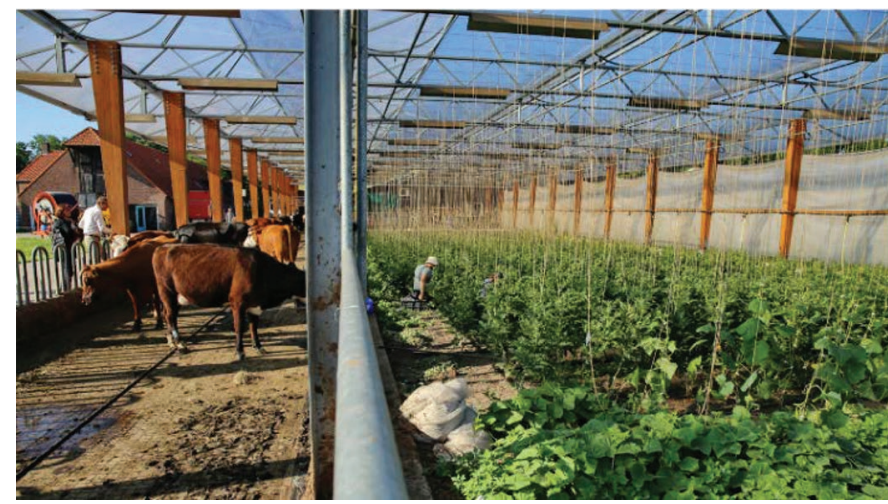

Figure 5. Use of composted bedding in freewalk housing for horticulture during the grazing period (Veld en Beek, Doorwerth farm, Heelsum, the Netherlands).

adjacent to the building. Based on information from sensors (ear, neck, or leg) or cameras, problem cows could be selected using selection gates to provide them with more space in the FW area inside or outside the main building.

To increase the capital efficiency of a building, one option is to use the building for other activities in the summer, when cows and young stock are grazing. Milking can still take place in the parlor if the layout is appropriate. Figure 5 shows the use of the building for horticulture (example in the Netherlands), and Figure 6 shows the use of the building for fattening pigs (example in Slovenia). When using the building for horticulture, sufficient light in the building is important, and extra soil on top is needed to grow paprika, tomatoes, or other vegetables or fruits. For fattening pigs, it is important to check for any risk of pig infection by bacteria in the bedding material. Experience from the Educational Research Centre Logatec (Logatec, Slovenia) in recent years has not indicated adverse effects on

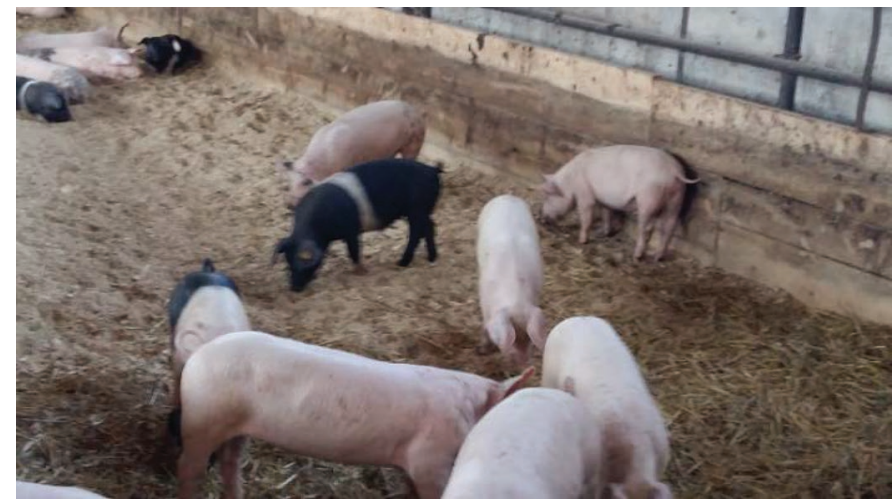

Figure 6. Use of freewalk housing for fattening pigs during the grazing period (Logatec farm, Slovenia). disease incidence (Klopcic et al., 2019). Multifunctional use of such a housing system brings farmers additional income while using available (family) labor and existing facilities.

\section{Floating Farm, Circular Economy, and Society}

In most countries, dairy farming is a land-based enterprise. Farmers use roughage and sometimes (part of the) concentrates from their own land. A land-based system decreases the import of feed and export of manure at the farm level. However, in many countries, urbanization is ongoing, and people are relocating from rural to urban areas. This trend prompts the question of whether animals should be kept close to where the feed is produced or where the animal products are consumed. If waste from cities and industry can be used as feed for animals, a city-based farming system could be an alternative. The floating farm in the Port of Rotterdam is the first floating dairy farm in the world to be based on this idea (Figure 7). It is an innovative concept that represents a circular means of producing food close to the consumers in the city; it was developed by Peter van Wingerden (Beladon Inc., Rotterdam, the Netherlands), who used to work on floating constructions. He suggests that this type of dairy housing would be suitable for cities situated in delta areas, thus reducing transport costs to consumers and benefiting from local residual flows from existing sources of production, such as waste products from breweries, mills, and potato processing. Circularity is an essential principle for floating farms and future farms in general. Water supply and drainage, generation of energy, waste process-

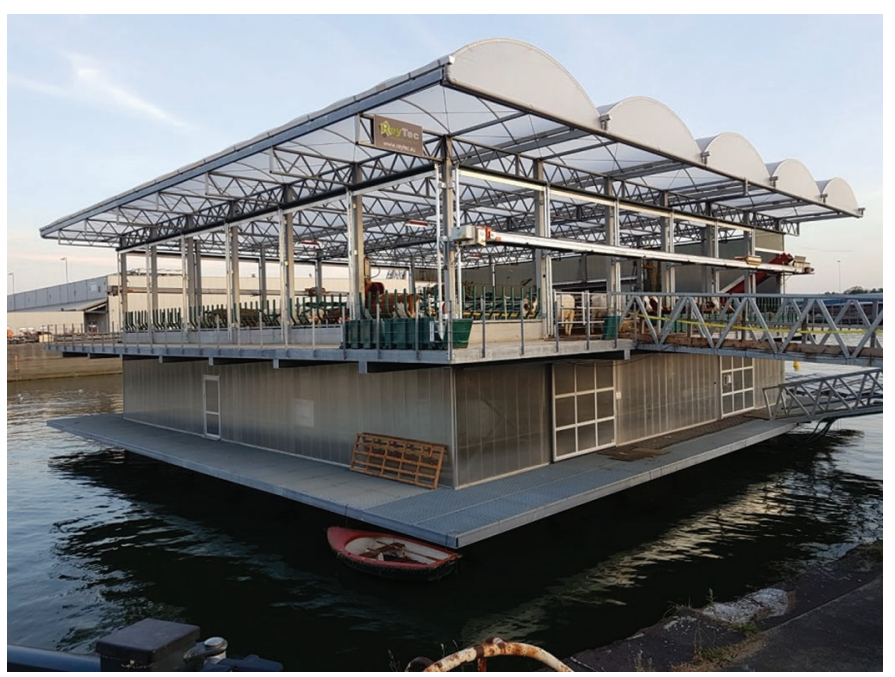

Figure 7. Floating dairy farm in Rotterdam, the Netherlands. 
ing, and feeding will all be part of the floating farm's "closed system." The use of solar energy, the collection of urine and manure for recycling into compost, the cleaning and reuse of rain water, and the production of cattle fodder with LED lighting and water plants all become integrated parts of this novel farm system (van Wingerden, 2019). Hydroponic feed production has generated considerable interest, and related projects are underway, such as the use of duckweed and seaweed as protein sources to be fed to dairy cattle as well as sheep, goats, pigs, and poultry (Makkar et al., 2016; Sońta et al., 2019).

\section{DISCUSSION AND CONCLUSIONS}

The development of dairy housing systems in the past, currently, and the future is a result of using technical innovations that have anticipated, in a smart manner, changes in sustainable thinking. Animal welfare issues, especially less lameness and fewer hock lesions, and more natural behavior, less emissions of ammonia and GHG, reuse of waste products, climate control, the aesthetics of the building in the landscape, increased capital efficiency, and increased manure quality are the main drivers of future housing systems. Being aware of conflicts among these aspects is important. Notably, more space per cow affects building costs, the landscape, and emissions. Research on FW systems with wood chips or sawdust has demonstrated that more space per cow can lower ammonia emission in the barn, despite the much greater emitting surface per cow. A point of concern is the availability of bedding materials; FW and CB systems that separate feces from urine and remove these quickly from the barn have great potential to reduce emissions of ammonia and GHG, and to improve fertilization of grassland and arable land. Vertical separation of feces and urine by using plates on a slatted or solid floor also appears promising from an animal welfare point of view, because the floor is drier and less slippery for cows than conventional floors. The potential of sand as bedding in a bedded-pack barn should be further explored. These developments can be promoted by introducing housing certificates with a milk price premium, as has been done by the Dutch Dairy Chain, or in other ways.

To make future housing even more acceptable to society, barns can be constructed with reusable and recyclable materials, thus limiting the environmental footprint of the building. Because it provides more space for the animals, the FW housing system would facilitate keeping calves together with their dams. For countries that must address heat stress, a possible innovation is to create a microclimate in $\mathrm{FW}$ or $\mathrm{CB}$ housing systems. A multi-climate building combining high-tech practices is in a stage of development with the aim of capturing and decreasing emissions.

To reduce food transportation cost and to reuse waste from large cities' industrial and human output, building farms in cities, such as floating farms, may be an interesting possibility for delta areas. The feasibility of a city-based farming system is strongly determined by whether the system is able to make use of waste from the city or grow forage on the water to feed the animals and create added value for the farms' manure products. However, the most common choice is a landbased farming system using grass, alfalfa, and maize as roughage. Therefore, the floating farm should also be assessed as a system for other animals, such as pigs and poultry, which use less roughage from land and more industrial byproducts.

As buildings become larger because of more space per cow and an increasing number of cows, and given that grazing is preferred in some parts of the world, using the building during summer for horticulture or other animals, such as pigs or broilers, could be economically advantageous and would enhance capital efficiency.

Future housing designs can be based on a combination of the beneficial features of FW and $\mathrm{CB}$ and new techniques. Young stock, dry cows, special needs cows, and perhaps also fresh cows may benefit more from freewalk systems, and high-yielding dairy cows could be kept in well-designed cubicles with animal-friendly bedding and with low-emission walkable floors. Sensors could be used to guide cows to particular housing areas. Separation of manure and urine complements the future housing system, whereas tools and techniques like CowToilet and capturing gases may be part of the system as well.

\section{ACKNOWLEDGMENTS}

This study was financially supported by the European Union's Horizon 2020 Research and Innovation Program under grant agreement No 696231, for research carried out within the ERA-NET SusAn project "FreeWalk." The authors have not stated any conflicts of interest.

\section{REFERENCES}

Adams, A. E., J. E. Lombard, C. P. Fossler, I. N. Román-Muñiz, and C. A. Kopral. 2017. Associations between housing and management practices and the prevalence of lameness, hock lesions, and thin cows on US dairy operations. J. Dairy Sci. 100:2119-2136. https://doi.org/10.3168/jds.2016-11517.

Barberg, A., M. I. Endres, and K. A. Janni. 2007. Compost dairy barns in Minnesota: A descriptive study. Appl. Eng. Agric. 23:231238. https://doi.org/10.13031/2013.22606. 
Beaver, A., C. Ritter, and M. A. G. von Keyserlingk. 2019. The dairy cattle housing dilemma. Natural behavior versus animal care. Vet. Clin. North Am. Food Anim. Pract. 35:11-27. https://doi.org/10 .1016/j.cvfa.2018.11.001.

Bewley, J. M., L. M. Robertson, and E. A. Eckelkamp. 2017. A 100Year Review: Lactating dairy cattle housing management. J. Dairy Sci. 100:10418-10431. https://doi.org/10.3168/jds.2017-13251.

Black, R. A., J. L. Taraba, G. B. Day, F. A. Damasceno, and J. M. Bewley. 2013. Compost bedded pack dairy barn management, performance, and producer satisfaction. J. Dairy Sci. 96:8060-8074. https://doi.org/10.3168/jds.2013-6778.

Blanco-Penedo, I., W. Ouweltjes, E. Ofner-Schrock, K. Brugemann, and U. Emanuelsen. 2020. Symposium review: Animal welfare in free-walk systems in Europe. J. Dairy Sci. 103. https://doi.org/ https://doi.org/10.3168/jds.2019-17315.

CBS. 2017. [Upscaling farms does not lead to less grazing]. Accessed Nov. 14, 2019. https://www.cbs.nl/nl-nl/nieuws/2017/40/ schaalvergroting-leidt-niet-tot-minder-koeien-in-de-wei.

Clay, N., T. Garnett, and J. Lorimer. 2020. Dairy intensification: Drivers, impacts and alternatives. Ambio 49:35-48. https://doi.org/10 .1007/s13280-019-01177-y.

Driehuis, F., E. Lucas-van den Bos, and M. H. J. Wells-Bennik. 2012. Risico's van microbiële contaminanten van strooisels: compost, geschieden mest, paardenmest en vrijloopstallen. NIZO (Nederlands Instituut voor Zuivel Onderzoek), Ede, the Netherlands.

Duurzame Zuivelketen. 2017. [Goals of the Dutch dairy chain]. Accessed Nov. 14, 2019. https://www.duurzamezuivelketen.nl/ resources/uploads/2017/12/gedetailleerde-doelen-duurzame -zuivelketen.pdf.

Endres, M. I., and A. E. Barberg. 2007. Behavior of dairy cows in an alternative bedded-pack housing system. J. Dairy Sci. 90:41924200. https://doi.org/10.3168/jds.2006-751.

Fávero, S., F. V. R. Portilho, A. C. R. Oliveira, H. Langoni, and J. C. F. Pantoja. 2015. Factors associated with mastitis epidemiologic indexes, animal hygiene, and bulk milk bacterial concentrations in dairy herds housed on compost bedding. Livest. Sci. 181:220-230. https://doi.org/10.1016/j.livsci.2015.09.002.

Galama, P. J., H. C. d. Boer, H. J. van Dooren, W. Ouweltjes, and F. Driehuis. 2015. Sustainability aspects of ten bedded-pack dairy barns in the Netherlands. Wageningen Livestock Research, Wageningen, the Netherlands.

Galama, P. J., H. J. C. van Dooren, and C. H. A. M. Eilers. 2012. Learning from drivers and conflicts around bedded-pack barns. 10th European IFSA (International Farming System Association) Symp., Aarhus, Denmark. IFSA Europe Group, Vienna, Austria.

Giller, K. E., C. Leeuwis, J. A. Andersson, W. Andriesse, A. Brouwer, P. Frost, P. Hebinck, I. Heitkönig, M. K. van Ittersum, N. Koning, R. Ruben, M. Slingerland, H. Udo, T. Veldkamp, C. van de Vijver, M. T. van Wijk, and P. Windmeijer. 2008. Competing claims on natural resources: What role for science? Ecol. Soc. 13:art34. https://doi.org/10.5751/ES-02595-130234.

Hammond, L. 2015. Nutrient availability and dynamics of compost bedded pack dairy barn waste. MS thesis. Department of Plant and Soil Sciences, University of Kentucky. https://uknowledge.uky .edu/pss_etds/68.

Horizon Europe. 2019. Horizon Europe 2021-2027: The next research and innovation framework programme. Accessed Nov. 14, 2019. https://ec.europa.eu/info/horizon-europe-next-research-and -innovation-framework-programme_en.

Jacobs, J. A., and J. M. Siegford. 2012. Invited review: The impact of automatic milking systems on dairy cow management, behavior, health, and welfare. J. Dairy Sci. 95:2227-2247. https://doi.org/ 10.3168/jds.2011-4943.

Johnsen, J. F., K. A. Zipp, T. Kälber, A. M. Passillé, U. Knierim, K. Barth, and C. M. Mejdell. 2016. Is rearing calves with the dam a feasible option for dairy farms? Current and future research. Appl. Anim. Behav. Sci. 181:1-11. https://doi.org/10.1016/j.applanim .2015.11.011.
Kester, E., M. Holzhauer, and K. Frankena. 2014. A descriptive review of the prevalence and risk factors of hock lesions in dairy cows. Vet. J. 202:222-228. https://doi.org/10.1016/j.tvjl.2014.07.004.

Khanal, A. R., J. Gillespie, and J. MacDonald. 2010. Adoption of technology, management practices, and production systems in US milk production. J. Dairy Sci. 93:6012-6022. https://doi.org/10 $.3168 /$ jds.2010-3425.

Klaas, I. C., B. Bjerg, S. Friedmann, and D. Bar. 2010. Cultivated barns for dairy cows: An option to promote cattle welfare and environmental protection in Denmark. Dansk Vettidsskr. 93:20-29.

Klopčič, M., P. Galama, and A. Kuipers. 2019. Innovation in housing and management systems for dairy cows. Pages 95-100 in Proc. 28th Int. Sci. Symp. Nutr. Farm Animals. T. Čeh, and S. Kapun ed. Zadravec-Erjavec Days, Radenci, Slovenia. [summary in English]

Kull, J. A., H. D. Ingle, R. A. Black, N. L. Eberhart, and P. D. Krawczel. 2017. Effects of bedding with recycled sand on lying behaviors udder hygiene, and preference of lactating Holstein dairy cows. J. Dairy Sci. 100:7379-7389. https://doi.org/10.3168/jds.2016-12307.

Leso, L. M. Barbari, M. A. Lopes, F. A. Damasceno, P. Galama, J. L. Taraba, and A. Kuipers. 2020. Invited review: Compost beddedpack barns for dairy cows. J. Dairy Sci. 103:1072-1099. https://doi .org/10.3168/jds.2019-16864.

Leso, L., L. Conti, G. Rossi, and M. Barbari. 2018. Criteria of design for deconstruction applied to dairy cows housing: A case study in Italy. Agron. Res. (Tartu) 16:794-805. https://doi.org/10.15159/ ar.18.085.

Leso, L., W. Morshed, L. Conti, and M. Barbari. 2017. Evaluating thermal performance of experimental building solutions designed for livestock housing: The effect of greenery systems. Agron. Res. (Tartu) 15:239-248.

Lombard, J. E., C. B. Tucker, M. A. G. von Keyserlingk, C. A. Kopral, and D. M. Weary. 2010. Associations between cow hygiene, hock injuries, and free stall usage on U.S. dairy farms. J. Dairy Sci. 93:4668-4676. https://doi.org/10.3168/jds.2010-3225.

Makkar, H. P. S., G. Tran, V. Heuzé, S. Giger-Reverdin, M. Lessire, F. Lebas, and P. Ankers. 2016. Seaweeds for livestock diets: A review. Anim. Feed Sci. Technol. 212:1-17. https://doi.org/10.1016/ j.anifeedsci.2015.09.018.

Meagher, R. K., A. Beaver, D. M. Weary, and M. A. G. von Keyserlingk. 2019. Invited review: A systematic review of the effects of prolonged cow-calf contact on behavior, welfare, and productivity. J. Dairy Sci. 102:5765-5783. https://doi.org/10.3168/jds.2018 $-16021$.

Palmer, R. and B. Holmes. 2005. Cow comfort issues in freestall barns. Pages 141-156 in Proc. 7th Western Dairy Management Conf., Reno, NV. Am. Dairy Sci. Assoc., Champaign, IL.

Rios, F. C., W. K. Chong, and D. Grau. 2015. Design for disassembly and deconstruction-Challenges and opportunities. Procedia Eng. 118:1296-1304. https://doi.org/10.1016/j.proeng.2015.08.485.

Rowbotham, R. F., and P. L. Ruegg. 2016. Bacterial counts on teat skin and in new sand, recycled sand, and recycled manure solids used as bedding in freestalls. J. Dairy Sci. 99:6594-6608. https:// doi.org/10.3168/jds.2015-10674.

Schils, R. L. M., A. P. Philipsen, G. Holshof, R. L. G. Zom, I. E. Hoving, C. G. Van Reenen, J. T. N. Van der Werf, P. J. Galama, L. Sebek, C. W. Klootwijk, N. van Eekeren, N. Hoekstra, M. W. Stienezen, and A. Van den Pol-Van Dasselaar. 2018. Amazing grazing: Science in support of future grass based dairy systems. Pages 336-338 in Proc. 23 EGF (European Grassland Federation) 2018: Sustainable meat and milk production from grasslands, Cork, Ireland. Teagasc, Cork, Ireland.

Somers, J. G. C. J., K. Frankena, E. N. Noordhuizen-Stassen, and J. H. M. Metz. 2003. Prevalence of claw disorders in Dutch dairy cows exposed to several floor systems. J. Dairy Sci. 86:2082-2093. https://doi.org/10.3168/jds.S0022-0302(03)73797-7.

Sońta, M., A. Rekiel, and M. Batorska. 2019. Use of duckweed (Lemna L.) in sustainable livestock production and aquaculture - A review. 
Ann. Anim. Sci. 19:257-271. https://doi.org/10.2478/aoas-2018 -0048 .

Sprecher, J. R. 2019. Multi-climate and low gas and odor emissionAnimal housing shed. A personal description. Sprecher Architects, Tel Aviv, Israel.

Steinfeld, H., P. Gerber, T. Wassenaar, V. Castel, M. Rosales, and C. de Haan. 2006. Livestock's long shadow: Environmental issues and options. Food and Agricultural Organization of the United Nations, Rome, Italy.

USDA. 2016. Dairy cattle management practices in the United States, 2014. Accessed Nov. 14, 2019. https://www.aphis.usda.gov/animal health/nahms/dairy/downloads/dairy14/Dairy14_dr_PartI.pdf.

van Dijk, W., and P. Galama. 2019. De maat van mest: perspectief van mestbewerking op de boerderij voor akkerbouwers en melkveehouders. Report 1157. Wageningen Livestock Research Wageningen, the Netherlands.

van Dooren, H. J. C., J. M. G. Hol, K. Blanken, and P. J. Galama. 2019. Gasvormige emissies uit vrijloopstallen met houtsnipperbodems. Ammoniak-, lachgas en methaanemissie op stalniveau. Wageningen Livestock Research, Wageningen, the Netherlands.

van Wingerden, P. 2019. Floating farm. Accessed Nov. 14, 2019. https: //www.dezeen.com/2019/05/24/floating-farm-rotterdam-climate -change-cows-dairy/.
Ventura, B. A., M. A. G. von Keyserlingk, H. Wittman, and D. M. Weary. 2016. What difference does a visit make? Changes in animal welfare perceptions after interested citizens tour a dairy farm. PLoS One 11:e0154733. https://doi.org/10.1371/journal.pone .0154733 .

Verdoes, N., and S. Bokma. 2017. Scheiding van urine en feces bij melkvee: fysiologie, gedragsherkenning en techniek. Report no. 1041. Wageningen Livestock Research, Wageningen, the Netherlands.

\section{ORCIDS}

P. J. Galama ( https://orcid.org/0000-0001-9514-678X

W. Ouweltjes (ㄴ) https://orcid.org/0000-0001-5455-0110

M. I. Endres ๑ https://orcid.org/0000-0002-1798-3432

L. Leso (ㄴ) https://orcid.org/0000-0003-4274-3921

A. Kuipers () https://orcid.org/0000-0001-7301-943X 


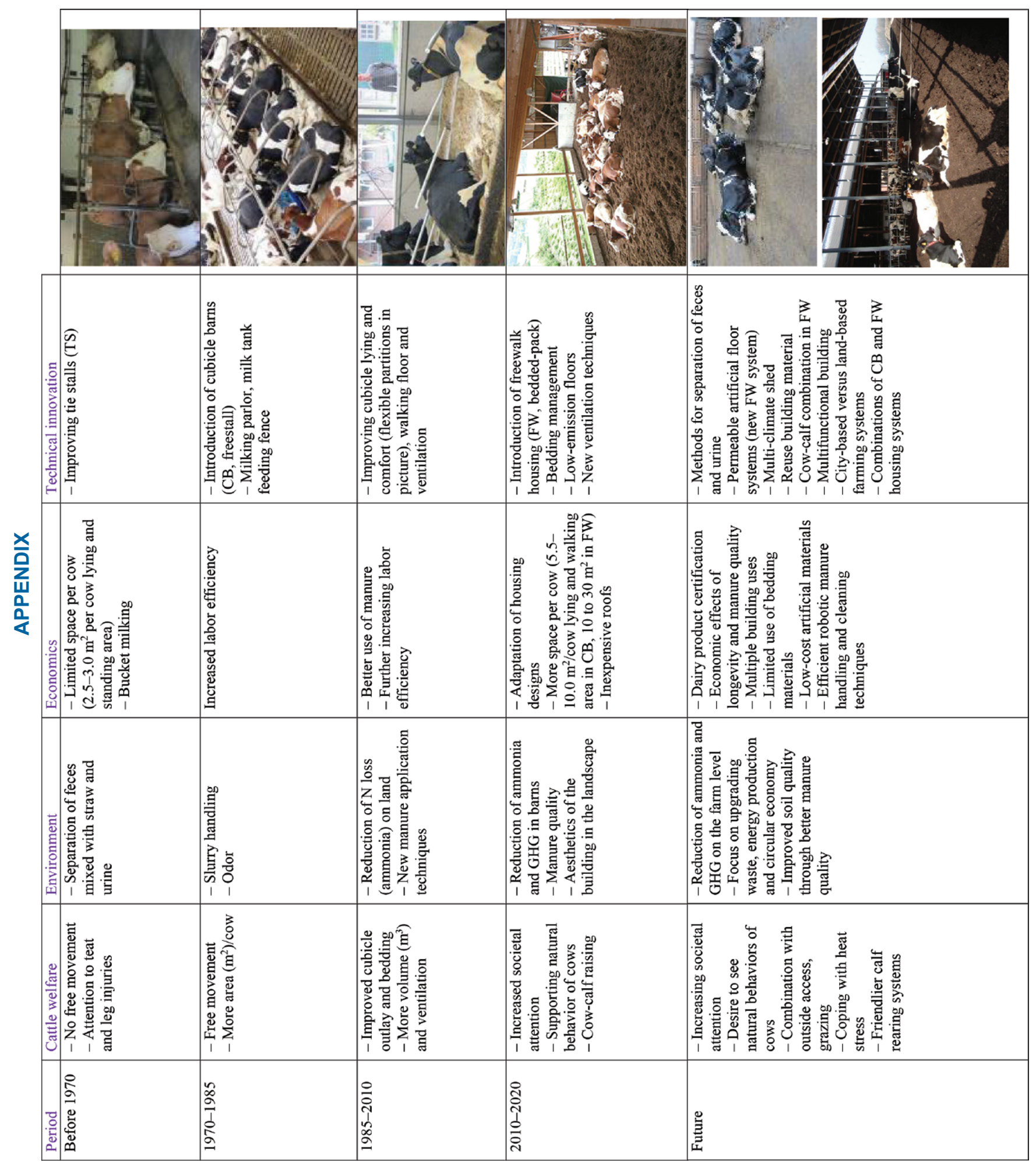




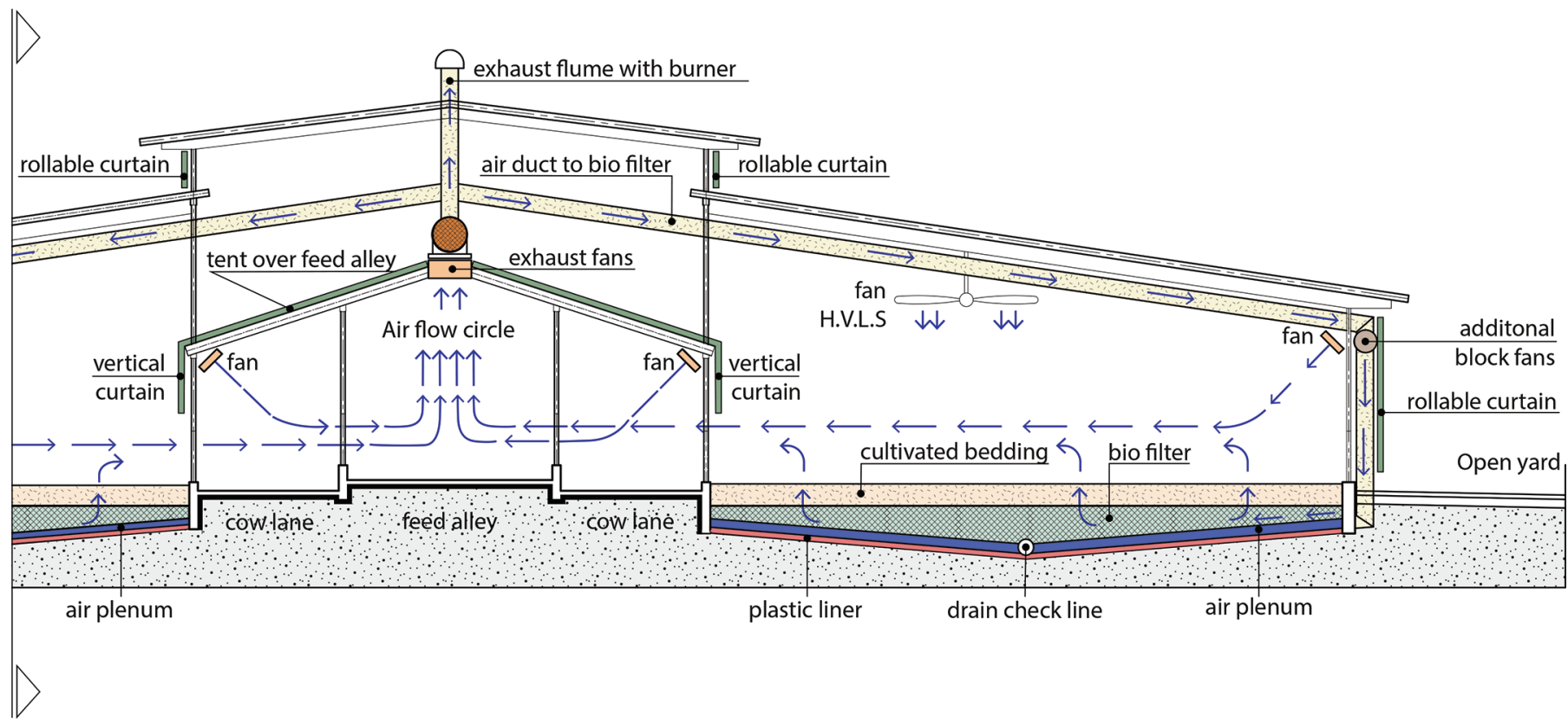

Figure A2. Concept of multi-climate and low gas and odor emission animal housing (Sprecher, 2019). 